\title{
Coulisses
}

Revue de théâtre

10 | Printemps 1994

Varia

\section{Maître Puntila et son valet Matti de Bertolt Brecht}

\section{(2) OpenEdition}

1 Journals

Édition électronique

URL : http://journals.openedition.org/coulisses/2934

DOI : $10.4000 /$ coulisses.2934

ISSN : 2546-9460

Éditeur

Presses universitaires de Franche-Comté

\section{Édition imprimée}

Date de publication : 1 juin 1994

Pagination : 34

ISSN : 1150-594X

\section{Référence électronique}

"Maitre Puntila et son valet Matti de Bertolt Brecht », Coulisses [En ligne], 10 | Printemps 1994, mis en

ligne le 15 mars 2019, consulté le 26 octobre 2019. URL : http://journals.openedition.org/coulisses/ 2934 ; DOI : 10.4000/coulisses.2934

Ce document a été généré automatiquement le 26 octobre 2019.

Coulisses 


\section{Maître Puntila et son valet Matti de Bertolt Brecht}

Mise en scène d'Alain Mollot, Théâtre de la Jacquerie. Espace Planoise : 10-11-12 mars 1994.

1 Les portes s'ouvrent. Le magma de spectateurs qui s'était amassé à l'entrée s'engouffre dans la salle.

2 Sur la scène, les techniciens s'affairent aux derniers préparatifs. Quelques coups de balais, de ça, de là, sous l'œil attentif du chef-régisseur. Disposition d'accessoires, d'éléments de décors sous les indications de la scripte.

3 Les comédiens attendent, traversent le plateau, ajustent leur costume, s'échauffent, jaugent du regard la salle maintenant comble ; Jacques Alric n'en peut plus d'attendre. Il éructe. Place à Maître Puntila, place au Théâtre : que la représentation commence.

4 C'est le pianiste qui donne la note : musicien farfelu à la tête hirsute et à la voix délirante. Aux comédiens d'enchaîner dans le ton. Place à l'ivresse.

5 Ils jouent de concert en gammes: du comique et du dérisoire des êtres et de leur solitude, ponctuées par les interventions insolites des régisseurs plateau.

6 La distanciation brechtienne fonctionne à merveille, n'enlevant rien au rythme de la pièce. Bien au contraire, chaque intervention redynamise le spectacle. A tel point que lorsque s'achève la représentation au bout de trois heures quinze, le spectateur n'éprouve pas l'envie de quitter la salle. Un moment exceptionnel de Théâtre comme on n'en rencontre que très rarement.

7 Maître Puntila a su nous faire partager son ivresse et on en reprendrait volontiers une tournée. 
Maître Puntila

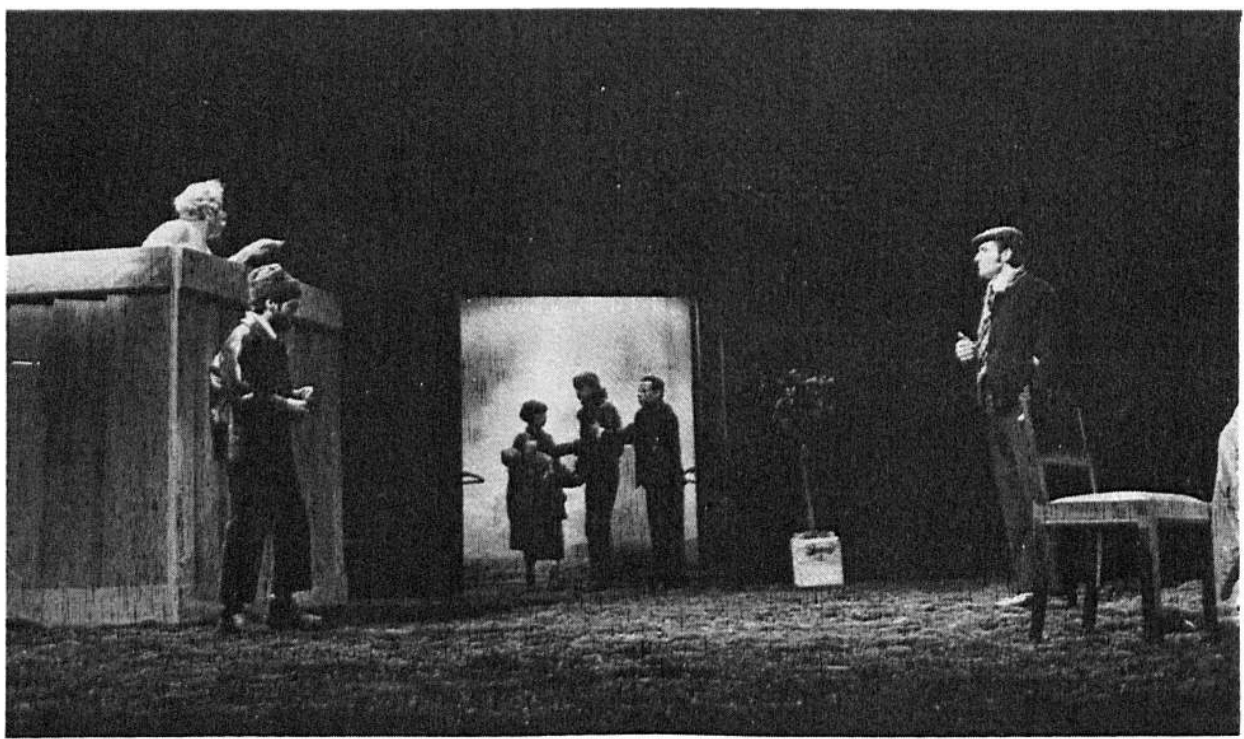

